\title{
Analysis of Automatically Switched Optical Network (ASON) Protection System in Jakarta - Bogor Fiber- Optic Transmission Link
}

\author{
Dika Fadilah Abduhuu', Peby Wahyu Purnawan ${ }^{2}$ \\ \{dika.fadilah@gmail.com ${ }^{1}$, pebywahyupurnawan@budiluhur.ac.id ${ }^{2}$ \} \\ Faculty of EngineeringUniversitas Budi Luhur, Jl. Ciledug Raya, Jakarta, Indonesia ${ }^{1,2}$
}

\begin{abstract}
The use of protection on fiber-optic network was to prevent the possibility of failures it was required reliable protection system to keep the service running. The process to find appropriate protection systems on Synchronous Digital Hierarchy (SDH) and Wavelength Division Multiplexing (WDM) networks was based on traffic distribution capacity, network topology, and economic considerations. There were several types of protection: Multiplex Section Protection (MSP), Sub-Network Connection Protection (SNCP), and Automatically Switched Optical Network (ASON). The protection system discussed in this thesis was Automatically Switched Optical Network (ASON) used by Mora Telematika Indonesia Inc. The test results and analysis conducted on the main line and ASON protection were revealed that ASON protection quality which able to handle multiple fault so that the traffic automatically moved to the protection line via Depok $=15.1324 \mathrm{~ms}$, via Graha $=26.6358 \mathrm{~ms}$, and via BSD = $49.6828 \mathrm{~ms}$; in accordance with standardization of Service Level Agreement (SLA) with switching time provider $<50 \mathrm{~ms}$ which was in the same quality between throughput, frame loss, jitter and the main line. Thus ASON protection kept the traffic running normally.
\end{abstract}

Keywords: Protection System, SDH, WDM, MSP, SNCP, ASON.

\section{Introduction}

The usage of fiber-optic transmission media as the backbone of Synchronous Digital Hierarchy (SDH) and Wavelength Division Multiplexing (WDM) technology that able to provide large traffic capacity is to prevent the worst possible system failure due to the damage of fiber-optic cable, and thus it needs reliable protection system to keep the service running[1], [2]. The protection system is chosen based on the needs of traffic, network topology, and economic considerations[3].

In principle, this protection system provides or takes some network capacity to be allocated as capacity in the backup channel. In this study, the system of Automatically Switched Optical Network (ASON) Jakarta - Bogor was developed for analyzing the switching time that is required for automatic restore and latency comparison which occurs in each router from ASON protection system on fiber-optic transmission network in the area of Jakarta-Bogor, along with the feasibility of ASON protection system. 


\section{Research Methodology}

\subsection{Automatically Switched Optical Network (ASON)}

ASON is an Optical Transport Network (OTN) that has the ability to establish a dynamic connection [4], [5]. ASON definition is set in ITU-T G.8081/Y.1353 on Terms and Definitions for Automatically Switched Optical Network (ASON). The recommendation explains all the terms, definitions, and abbreviations used in ASON recommendations [6]. ASON protection system is able to overcome multiple fault cases which each connected line can be used simultaneously, and if fiber failure (fiber cut) occurred, the traffic will automatically move through the normal connected lines [7].

\subsection{ASON Architecture}

ASON architecture is divided into three parts (planes), i.e. transport plane, control plane, and management plane [5], as shown in Figure 1

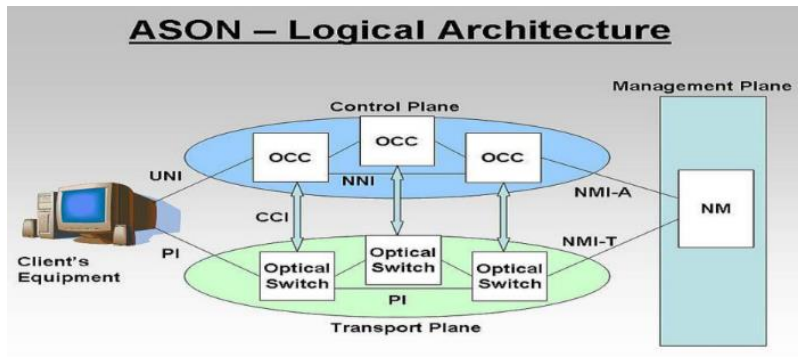

Fig. 1. Architecture of ASON [8]

\section{- Transport Plane}

Transport plane is also known as data plane which represents the use of network resources to convey information among users.

\section{- Control Plane}

Control plane includes the process of signaling, routing, and link management. Signaling performs the development process, disconnections, and modifies connections.

\section{○ Management Plane}

Management plane provides network management functions on transport plane and control plane, and the system as a whole. [9], [10] ASON uses a restoration or protection system and both that isPRC (Protection Restoration Combine) as its fault handling. While the backbone network is still using ring topology, in which the redundancy process uses the protection system (SNCP/MSP). With this topology, it is not possible for the network to have multiple 
fault handling. The condition of multiple fault handling is shown as in Figure 2 in which the mesh service topology will still run even though there are three failure links.
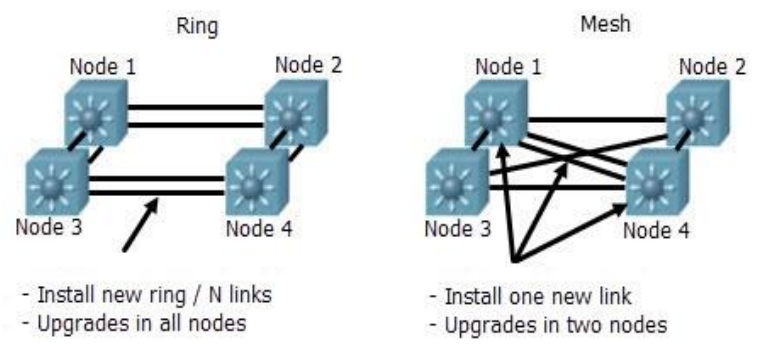

Fig. 2. Comparison of Ring and Mesh Topologies [11]

\subsection{Service Level Agreement (SLA)}

Service Level Agreement or commonly known as SLA is part of the overall service agreement between 2 (two) entities for performance improvement or in other words the delivery time must be fixed during the contract period. These two entities are typically known as service providers and clients that may concern legal agreement due to money involvement or any formal contracts between internal business units.

\subsection{Quality of Service (QoS)}

Quality of Service (QoS) or service quality is a network mechanism that allows applications or services to operate as expected. QoS is related to customer satisfaction on using the network. Some of QoS parameters are throughput, packet loss or frame loss, latency or delay, and jitter. The following QoS standards are used by Mora Telematika Indonesia, Inc., such as throughput, packet or frame loss, latency or delay, and jitter [12]:

\subsubsection{Throughput}

Throughput is the effective rate of data transfer which the data is measured in bps. Throughput can be calculated using equation 1 :

Table 1. Throughput Standardization.

\begin{tabular}{c|c}
\hline Category & Throughput (\%) \\
\hline Very Good & 100 \\
\hline Good & 95 \\
\hline Moderate & 90 \\
\hline Poor & $<85$ \\
\hline
\end{tabular}

$$
P=\frac{s}{t} \quad \text { or }
$$


Throughput $=\frac{\text { packet data received }}{\text { total of observation time }}$

where:

$\mathrm{t}=$ time used in transmitting data (seconds)

$\mathrm{s}=$ data size received (bit)

$\mathrm{P}=$ actual throughput at time of data transmission (bits per second)

\subsubsection{Packet or Frame Loss}

Packet loss or frame loss is a parameter that indicates the loosing number of packets or frame during the data transmission from the source (sender) to the destination (receiver). Packet loss can be calculated using equation 2 :

Table 2. Packet loss Standardization.

\begin{tabular}{cc}
\hline Category & Packet loss $(\%)$ \\
\hline Very Good & 0 \\
Good & 1 \\
Moderate & 3 \\
Poor & 5 \\
\hline
\end{tabular}

Packet Loss $=$

$\frac{(\text { data packet sent-data packet received })}{\text { data packet sent }} \times 100 \%$

\subsubsection{Latency or Delay}

Latency is the amount of time for data packet to move across a network connection. Latency can be calculated using equation 3 :

Table 3. Latency Standardization.

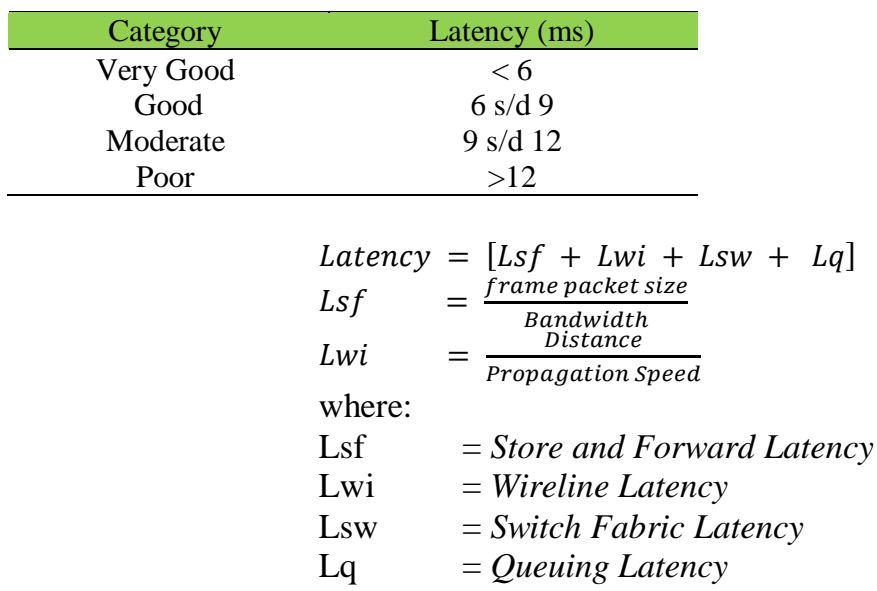




\subsubsection{Jitter}

Jitter is a delay variation due to time difference or interval between packet arrivals in Jitter recipient that can be calculated using equation 6:

Table 4. Jitter Standardization.

\begin{tabular}{cc}
\hline Category & Jitter $(\mathrm{ms})$ \\
\hline Very Good & 0 \\
Good & $0 \mathrm{~s} / \mathrm{d} 3$ \\
Moderate & $3 \mathrm{~s} / \mathrm{d} 6$ \\
Poor & $>6$ \\
\hline & Jitter $=\frac{\text { total of delay variation }}{\text { total of received packet }}$ \\
& Total of delay variation $=$ \\
& delay $-($ average delay $)$
\end{tabular}

\subsection{Implementation of Automatically Switched Optical Network Jakarta - Bogor Link}

\subsubsection{Flow Chart of Traffic Restoration}

In Figure 3, if a Fiber Failure or FO cut is detected in Jakarta - Bogor route, enabling the closest protection line will return the traffic to normal.

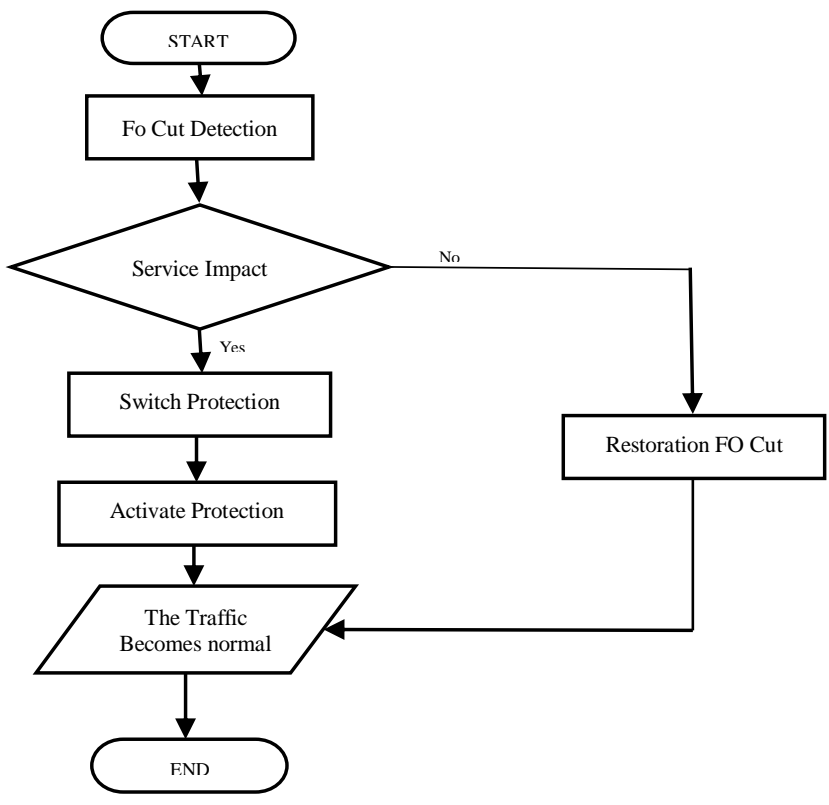

Fig. 3. Flow Chart of Traffic Restoration. 
(Start-FO cut detected-service impact-Y. switch to nearest protection-enable the protectiontraffic back to normal-finish; N. Wait for FO cut restoration-traffic back to normal-finish)

\subsubsection{Flow Chart of Traffic Restoration}

Jakarta - Bogor Network Topology is in direct core as shown in Figure 4, the traffic will be at high risk of interference if there is a fiber failure.

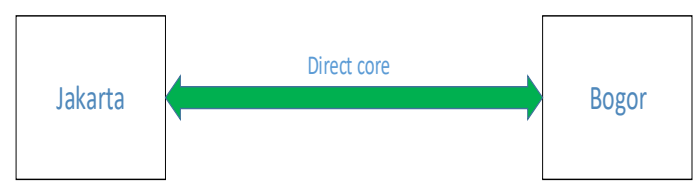

Fig. 4. Topology Core Jakarta - Bogor.

In the beginning, Jakarta - Bogor transmission network was formed by SDX 1xSTM64.

\subsubsection{Survivability Network Jakarta-Bogor}

Table 5 is a collection of fiber failure cases occurredin Jakarta - Bogor network during December 2016 up to March 2017.

Table 5. Historical Fiber Failure Data in Jakarta - Bogor Section.

\begin{tabular}{|c|c|c|c|c|c|c|}
\hline Section & Downtime & Uptime & $\begin{array}{c}\text { Over-all } \\
\text { down-time }\end{array}$ & $\begin{array}{l}\text { Route Cause } \\
\text { (Source) }\end{array}$ & $\begin{array}{c}\text { Detail } \\
\text { Problem }\end{array}$ & Action Taken \\
\hline $\begin{array}{l}2 \text { Core DWDM } \\
\text { Sec-tion Jakar-ta - } \\
\text { Bogor Down }\end{array}$ & $\begin{array}{c}\text { Dec 4, } 2016 \\
\text { 16:13:00 }\end{array}$ & $\begin{array}{c}\text { Dec 5, } \\
2016 \\
02: 33: 00\end{array}$ & $10 \mathrm{~h} 20 \mathrm{~m}$ & Bad core & $\begin{array}{l}\text { Patch core } \\
\text { problem at } \\
\text { Jakarta }\end{array}$ & $\begin{array}{l}\text { Link Back to } \\
\text { normal after } \\
\text { replace patch } \\
\text { core }\end{array}$ \\
\hline $\begin{array}{c}2 \text { Core DWDM sec- } \\
\text { tion Jakar ta - } \\
\text { Bogor Down }\end{array}$ & $\begin{array}{c}\text { Dec 14, } \\
2016 \\
04: 03: 00\end{array}$ & $\begin{array}{c}\text { Dec 16, } \\
2016 \\
05: 46: 00\end{array}$ & $2 \mathrm{D} 1 \mathrm{~h} 43 \mathrm{~m}$ & PU Activity & $\begin{array}{l}\text { FO cut } \\
\text { section } \\
\text { Cyber - } \\
\text { Bogor, cut } \\
\text { point } 4 \mathrm{Km} \\
\text { from POP } \\
\text { Bogor } \\
\text { FO cut } \\
\text { section }\end{array}$ & $\begin{array}{l}\text { Link up after } \\
\text { fiber splicing }\end{array}$ \\
\hline $\begin{array}{l}2 \text { Core SDH sec- } \\
\text { tion Jakar-ta - } \\
\text { Bogor Down }\end{array}$ & $\begin{array}{l}\text { Dec 14, } \\
2016 \\
16: 00: 00\end{array}$ & $\begin{array}{c}\text { Mar 13, } \\
2017 \\
20: 31: 00\end{array}$ & 89D 4h 31m & PU Activity & $\begin{array}{c}\text { Cyber - } \\
\text { Bogor, cut } \\
\text { point at } 3.8 \\
\text { KM from } \\
\text { Jakarta }\end{array}$ & $\begin{array}{l}\text { Link up after } \\
\text { fiber splicing }\end{array}$ \\
\hline $\begin{array}{c}2 \text { Core DWDM sec- } \\
\text { tion Jakar-ta }- \\
\text { Bogor Flicker }\end{array}$ & $\begin{array}{c}\text { Jan 6, } 2017 \\
16: 15: 00\end{array}$ & $\begin{array}{c}\text { Jan 6, } \\
2017 \\
16: 20: 00 \\
\end{array}$ & $5 \mathrm{~m}$ & Unknown & $\begin{array}{l}\text { Detect } \\
\text { alarm LOS } \\
\text { section }\end{array}$ & $\begin{array}{l}\text { Link back to } \\
\text { normal before } \\
\text { any further }\end{array}$ \\
\hline
\end{tabular}




\begin{tabular}{|c|c|c|c|c|c|c|}
\hline & & & & & $\begin{array}{l}\text { Jakarta - } \\
\text { Bogor }\end{array}$ & action \\
\hline $\begin{array}{l}2 \text { Core DWDM sec- } \\
\text { tion Jakar-ta - } \\
\text { Bogor Down }\end{array}$ & $\begin{array}{c}\text { Feb 19, } \\
2017 \\
01: 31: 00\end{array}$ & $\begin{array}{c}\text { Feb 19, } \\
2017 \\
14: 43: 00\end{array}$ & $13 \mathrm{~h} 12 \mathrm{~m}$ & PU Activity & $\begin{array}{l}\text { FO cut } \\
\text { section } \\
\text { Cyber - } \\
\text { Bogor, cut } \\
\text { point at } \\
21 \mathrm{~km} \text { from } \\
\text { Bogor }\end{array}$ & $\begin{array}{l}\text { Link up after } \\
\text { fiber splicing }\end{array}$ \\
\hline $\begin{array}{l}2 \text { Core DWDM sec- } \\
\text { tion Jakar-ta - } \\
\text { Bogor Flicker }\end{array}$ & $\begin{array}{c}\text { Feb 28, } \\
2017 \\
22: 53: 00\end{array}$ & $\begin{array}{l}\text { Feb } 28, \\
2017 \\
23: 02: 00\end{array}$ & $9 \mathrm{~m}$ & Unknown & $\begin{array}{c}\text { Detect } \\
\text { alarm LOS } \\
\text { section } \\
\text { Jakarta - } \\
\text { Bogor }\end{array}$ & $\begin{array}{l}\text { Link back to } \\
\text { normal after } \\
\text { any further } \\
\text { action }\end{array}$ \\
\hline $\begin{array}{l}2 \text { Core DWDM sec- } \\
\text { tion Jakar-ta - } \\
\text { Bogor Down }\end{array}$ & $\begin{array}{c}\text { Mar 1, } 2017 \\
11: 18: 00\end{array}$ & $\begin{array}{c}\text { Mar 1, } \\
\text { 2017 } \\
\text { 17:25:00 }\end{array}$ & $6 \mathrm{~h} 7 \mathrm{~m}$ & $\begin{array}{l}\text { Patch core } \\
\text { problem }\end{array}$ & $\begin{array}{l}\text { Patch core } \\
\text { problem at } \\
\text { Jakarta }\end{array}$ & $\begin{array}{l}\text { Link Back to } \\
\text { normal after } \\
\text { replace patch } \\
\text { core }\end{array}$ \\
\hline
\end{tabular}

\subsubsection{ASON Design Jakarta - Bogor}

This protection system technology is one of the protection system used by Mora Telematika IndonesiaInc.The use of Automatically Switched Optical Network (ASON) technology is based on the establishment of optical cable infrastructure that connects the city of Jakarta Bogor - Depok - Tangerang - Bekasi (JABODETABEK) that each city has been integrated to more than one city destination as shown in Figure 5.

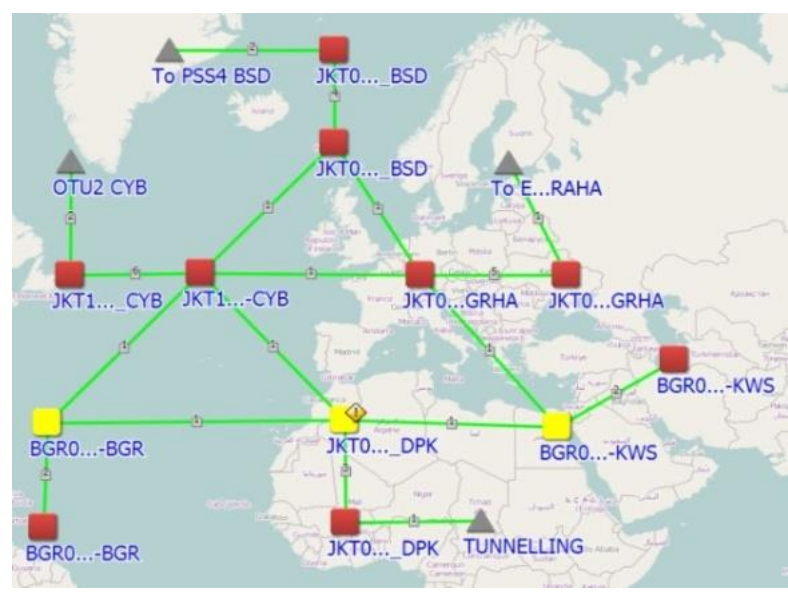

Fig. 5. Backbone Topology of JABODETABEK. 


\subsubsection{ASON Configuration and Implementation Jakarta - Bogor Link}

In applying this ASON configuration, there are some things to be concerned; determining the service definition that includes the capacity or rate and the allocation of the end-to-end port. In Jakarta - Bogorlink, this can be determined by the direction and purpose of the port, here are to create an ASON configuration in OMS:

1. Determining Jakarta - Bogor service definition link that will be used.

2. Configuring the Transmission Parameters such as:

- Action on LOS

- Container

- $\quad$ Signal Type

3. Configuring ASON, the main thing in ASON configuration is Default Priority and Default Setup Priority, which is as a priority link to occupy the protection allocation in ASON.

4. Configuring Assurance, this configuration aims to enable Performance Monitoring within 15 minutes and 24 hours. So that the links quality can be seen in case of failure occurs on the transmission network.

5. Implementing the configured link.

The result of Jakarta - Bogor ASON link that has been implemented can be seen in the highlight of CSO as in figure 6.

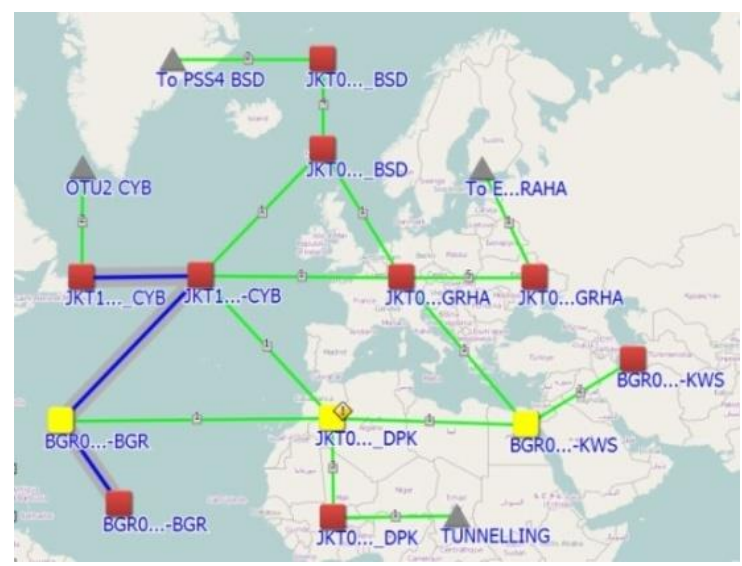

Fig. 6. ASON Highlight Jakarta - Bogor.

After the implementation ofASON protection system in Jakarta - BogorLink, it has the ability to cope with the traffic down if there is any fiber failure and has the ability to handle multiple fault cases if a fiber failure happens in the other line.

\subsubsection{BERTest}

Bit Error Rate Test is commonly used to find out numbers of errors that occur in communication networks, either in networks based on SDH technology, PDH, DSL, Fiber 
Channel and Ethernet. The parameters on BERTest are Throughput, Frame Loss, Latency, Jitter, and Switching time.

\subsubsection{Standardization of Service Level Agreement (SLA)}

Here are the SLA offered by Mora Telematika Indonesia, Inc.:

Table 6. Historical Fiber Failure Data in Jakarta - Bogor Section.

\begin{tabular}{cccc} 
Availability \% & $\begin{array}{c}\text { Downtime } \\
\text { Per Year }\end{array}$ & $\begin{array}{c}\text { Downtime } \\
\text { Per Month }\end{array}$ & $\begin{array}{c}\text { Downtime } \\
\text { Per Week }\end{array}$ \\
\hline 90 & $36,5 \mathrm{D}$ & $72 \mathrm{~h}$ & $16,8 \mathrm{~h}$ \\
95 & $18,25 \mathrm{D}$ & $36 \mathrm{~h}$ & $8,4 \mathrm{~h}$ \\
97 & $10,96 \mathrm{D}$ & $21,6 \mathrm{~h}$ & $5,04 \mathrm{~h}$ \\
98 & $7,30 \mathrm{D}$ & $14,4 \mathrm{~h}$ & $3,36 \mathrm{~h}$ \\
99 & $3,65 \mathrm{D}$ & $7,20 \mathrm{~h}$ & $1,68 \mathrm{~h}$ \\
99,5 & $1,83 \mathrm{D}$ & $3,60 \mathrm{~h}$ & $50,4 \mathrm{~m}$ \\
99,8 & $17,52 \mathrm{~h}$ & $86,23 \mathrm{~m}$ & $20,16 \mathrm{~m}$ \\
99,9 & $8,76 \mathrm{~h}$ & $43,8 \mathrm{~m}$ & $10,1 \mathrm{~m}$ \\
99,95 & $4,38 \mathrm{~h}$ & $21,56 \mathrm{~m}$ & $5,04 \mathrm{~m}$ \\
99,99 & $52,56 \mathrm{~m}$ & $4,32 \mathrm{~m}$ & $1,01 \mathrm{~m}$ \\
99,999 & $5,26 \mathrm{~m}$ & $25,9 \mathrm{~s}$ & $6,05 \mathrm{~s}$ \\
99,9999 & $31,5 \mathrm{~s}$ & $2,59 \mathrm{~s}$ & $0,605 \mathrm{~s}$ \\
99,99999 & $3,15 \mathrm{~s}$ & $0,259 \mathrm{~s}$ & $0,0605 \mathrm{~s}$ \\
\hline
\end{tabular}

For example, a customer with 99\% SLA; that means a standard service offered by Mora Telematika Indonesia, Inc. is $99 \%$ in a month and the remaining $1 \%$ of the service is considered to be normal to be down. In 1 month, if there are 30 days, which 1 day is 24 hours, then in 1 month $=30$ days $\times 24$ hours $=720$ hours is $100 \%$ up service. If it is $99 \%$, then the service standard is $99 \%$ x 720 hours $=712.8$ hours, which the rest 7.2 hours is considered as normal if the service go down (off) in 1 month. Referring to table 5, when a disruption happens to the transmission media network Jakarta - Bogor, its completion will take quite a long time so that SLA standardization is not possible to be reached. Thus to maintain the commitment of theSLA offered, in order to prevent the long traffic downtime, it is needed to implement ASON protection system.

\subsubsection{Standardization of Link Performance}

Standardization of link performance, besides referring to the value of Quality of Service $(\mathrm{QoS})$, is also seen from the switching time that required to restore the traffic. Here are the standardization parameters used by Mora Telematika Indonesia, Inc [12].

Table 7. Normal Link Parameter.

\begin{tabular}{ccc}
\hline Parameter & Value & Unit \\
\hline Throughput & 100 & $\%$ \\
Frame Loss & 0 & $\%$ \\
Latency & $<6$ & $\mathrm{~ms}$ \\
\hline
\end{tabular}




\begin{tabular}{ccc} 
Jitter & $<0$ & $\mathrm{~ms}$ \\
Switching Time & $<50$ & $\mathrm{~ms}$ \\
\hline
\end{tabular}

\section{Test and Analysis of Ason Protection System}

\subsection{Configuration Test of ASON Jakarta - Bogor Link}

Figure 7 is ASON Jakarta - Bogorconfiguration test image that is applied using BERTest.

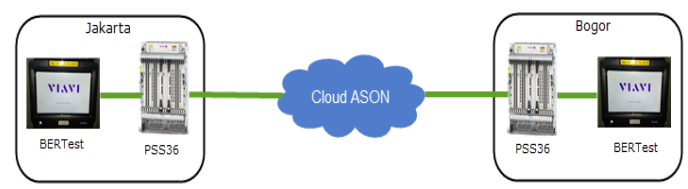

Fig. 7. Configuration Test.

\subsection{Line Analysis of Jakarta - Bogor Main Link}

\subsubsection{Throughput}

Figure 8 is the result of throughput measurement:

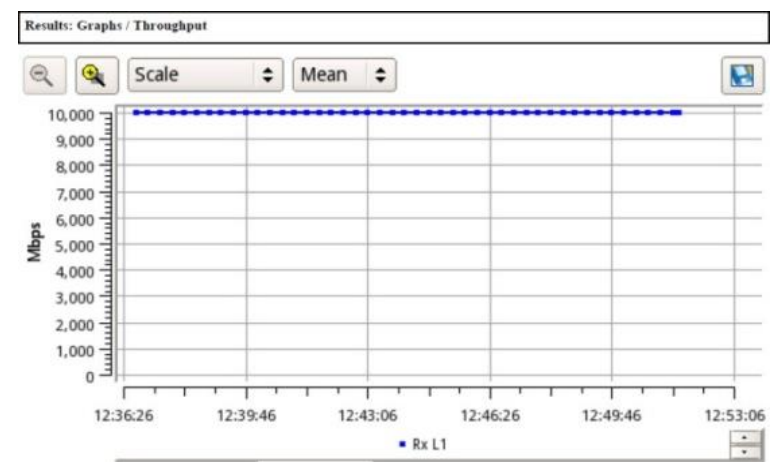

Fig. 8. Throughput Measurement of Jakarta - Bogor Main Link.

From the throughput measurement, it can be calculated using equation 1. A received packet from a total of 15 minutes test time is $1,122,616,156,800$ Bytes or 1,122 Tera Byte.

$\mathrm{S}=1,122,616,156,800$ Byte $\times 8=8,980,929,254,400$ bits; and $\mathrm{t}=15$ minutes $\mathrm{x} 60=900 \mathrm{~s}$

Then the throughput $(\mathrm{P})$ received is: 


$$
\begin{aligned}
\text { Throughput }= & \frac{\text { data packet received }}{\text { total of observation time }}=\frac{8,980,929,254,400 \mathrm{~b}}{900 \mathrm{~s}} \\
& =9,978,810,283 \mathrm{bps} \cong 9.979 \mathrm{Gbps}
\end{aligned}
$$

\subsubsection{Frame Loss or Packet Loss}

Figure 9 is the result of frame loss or packet loss measurements on Jakarta - Bogor main link network.

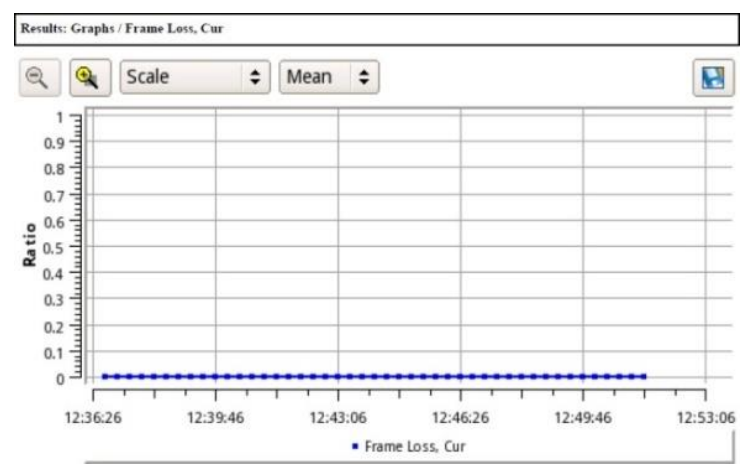

Fig. 9. Graphic of Frame Loss Measurement on Jakarta - Bogor Main Link.

From Figure 9 and Figure 10 the measurements line of Jakarta - Bogor main link fiber-optic transmission network with $10 \mathrm{Gbps}$ bandwidth has a frame loss or packet loss $0 \%$, which means with $100 \%$ success rate then all packets transmitted in the network are sent perfectly without any packet missing in its transmission.

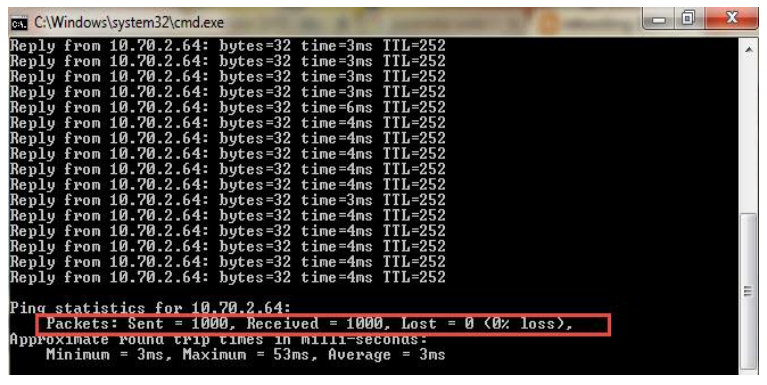

Fig. 10. Frame or Packet Loss Main Link Jakarta - Bogor.

From the measurement data of packet loss, it can be calculated by using equation 2.2. The packet sent $=1,000$ and Packet received $=1,000$.

Then the packet loss is:

$$
\text { Packet Loss }=\frac{(\text { data packet sent }- \text { data packet received })}{\text { data packet sent }} \times 100 \%
$$




$$
=\frac{(1,000-1,000)}{1,000} \times 100 \%=0 \%
$$

\subsubsection{Latency or delay}

The measurements are conducted by sending packets or pinging repeatedly 1,000 times with the default load of 9,600 bits, Switch Fabric Latency (Lsw) of $0.0512 \mathrm{~ms}$ and Queuing Latency $(\mathrm{Lq})=0 \mathrm{~ms}$. Below in figures 11 and 12 are the results of latency or delay measurements:

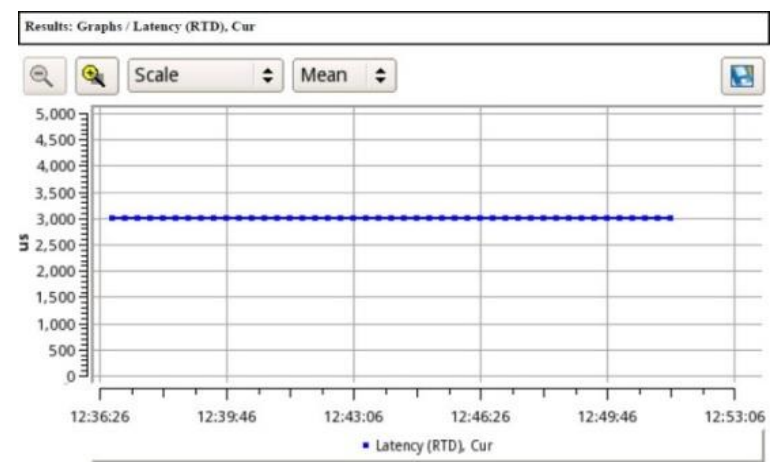

Fig. 11. Graphic of Latency Measurement of Jakarta - Bogor Main Link.

In Figure 11 the graphic of Latency Main Link measurement of fiber-optic transmission network from Jakarta - Bogor, the current latency can be seen $3000 \mu$ s or $3 \mathrm{~ms}$. From the results of ping test Jakarta - Bogor in figure 12 also can be seen the minimum Latency $=3 \mathrm{~ms}$, maximum $=53 \mathrm{~ms}$, and average $=3 \mathrm{~ms}$.

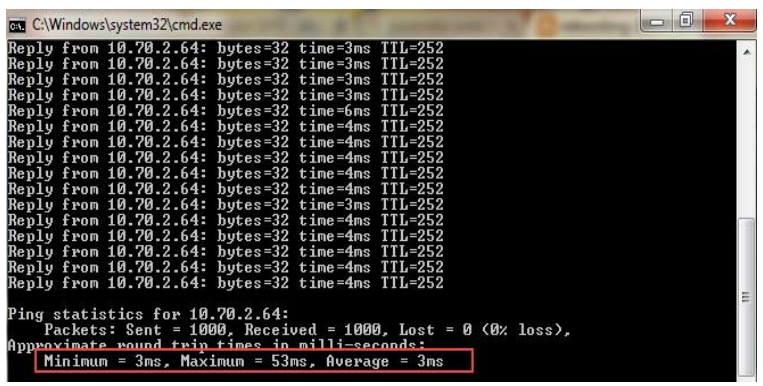

Fig. 12. Latency in Jakarta - Bogor Main Link.

From the measurement data conducted with bandwidth $10 \mathrm{Gbps}$, it can be calculated using equations $2.3,2.4$, and 2.5. With the known data as follows:

Frame packet size $=9,600$ bit $\times 1,000=9,600,000$ bits

Bandwidth $=10 \mathrm{Gbps}=10,000,000,000 \mathrm{bps}$

Distance of Jakarta - Bogor $=92 \mathrm{Km}=92,000 \mathrm{~m}$ 
Then the number of Store and Forward Latency (Lsf) and Wireline Latencty (Lwi) are:

$$
L s f=\frac{\text { frame packet size }}{\text { Bandwidth }}=\frac{9,600,000 \mathrm{bit}}{10,000,000,000 \mathrm{bps}}
$$

For Lwi number:

$$
\text { Lwi }=\frac{\text { Distance }}{\text { Propagation Speed }}=\frac{92,000 \mathrm{~m}}{3 \times 10^{8} \frac{\mathrm{m}}{\mathrm{s}}}
$$

From the calculation data above, it is known the latency number is as follows:

Latency $=[L s f+L w i+L s w+L q] \times 3$ hop $=[0.96+0.3067+0.0512+0] \times 3=1.3179$ $\mathrm{x} 3=3.9537 \mathrm{~ms}$

\subsubsection{Jitter}

Figure 13 shows the results of jitter measurements.

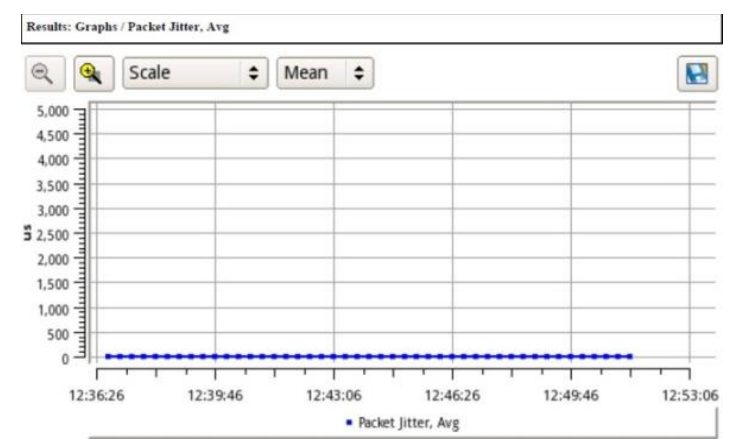

Fig. 13. Jitter in Jakarta - Bogor Main Link.

From the result of jitter measurement at Figure 13, it was seen the jitter value equal to $0 \mu \mathrm{s}$ with data of total packet received 1,122,616,156,800 Byte and total variation delay 3,9537 ms, thus it can be calculated using equation 2.6.

$$
\begin{aligned}
\text { Jitter } & =\frac{\text { total of delay variation }}{\text { total of received packet }}=\frac{3.9537 \times 10^{-3}}{1,122,616,156,800} \cong 3.5219 \\
& \cong 3.5219 \text { femto second }(\mathrm{fs})
\end{aligned}
$$

From the measurement data of QoS in Jakarta - Bogor main link with throughput parameter, frame loss or packet loss, latency, and jitter, there is difference in the calculation result which can be seen in table 8 below:

Table 8. Measurement and Calculation Results of QoS in Jakarta - Bogor Main Link. 


\begin{tabular}{ccc}
\hline QoS Parameter & Measurement & Calculation \\
\hline Throughput & $10 \mathrm{Gbps}$ & $9.979 \mathrm{Gbps}$ \\
Frame Loss & $0 \%$ & $0 \%$ \\
Latency & $3 \mathrm{~ms}$ & $3.9537 \mathrm{~ms}$ \\
Jitter & $0 \mu \mathrm{s}$ & $3.5219 \mathrm{fs}$ \\
\hline
\end{tabular}

\subsection{Line Analysis of Jakarta - Bogor Protection Link}

\subsubsection{Jakarta - Bogor Protection Link via Depok}

Here in Figure 14 was seen when Jakarta - Bogor main line went down and the traffic was going through Depok.

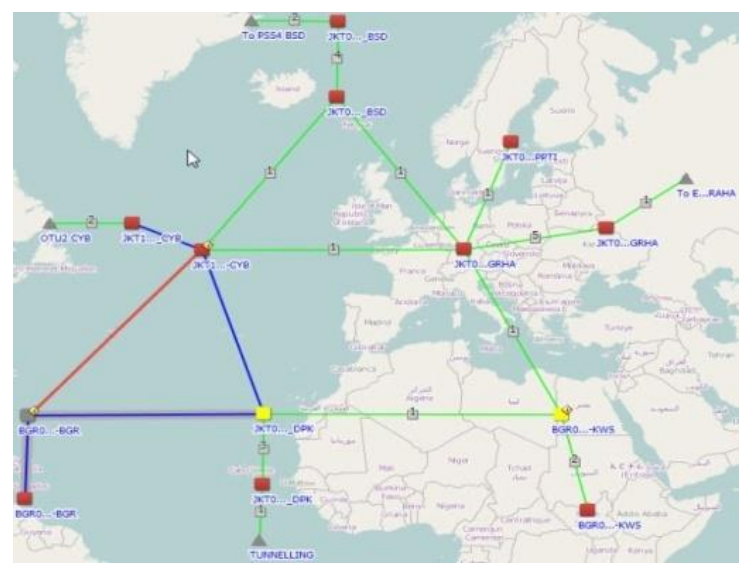

Fig. 14. Jakarta - Bogor Traffic via Depok.

\subsubsection{Jakarta - Bogor Protection Link via Graha - Kota Wisata - Depok}

When double failure occurred inJakarta - Bogor main line and protection line via Depok, the traffic will automatically move to another closer protection lineswitchare Jakarta - Grha Kota Wisata - Depok - Bogor, as shown in Figure 15. 


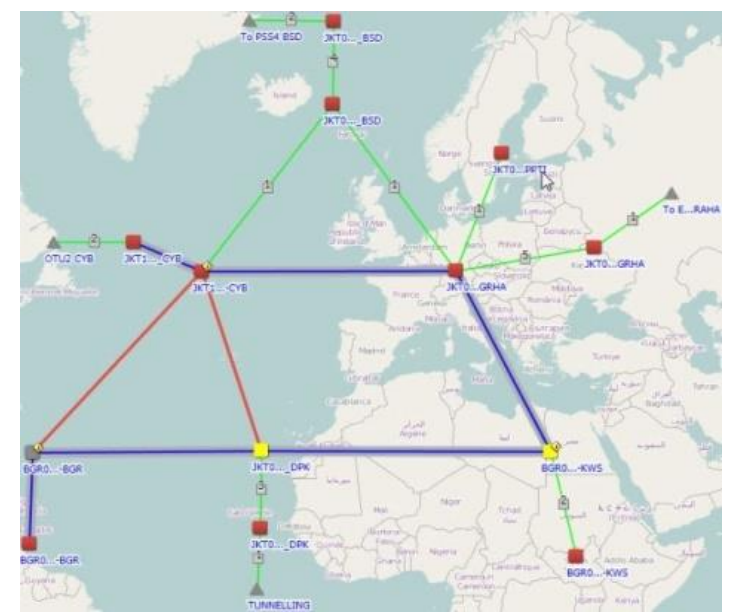

Fig. 15. Jakarta - Bogor Traffic via Graha.

\subsubsection{Jakarta - Bogor Protection Link via BSD - Graha - KotaWisata - Depok}

When a triple failure occurredinJakarta - Bogor main line, protection line via Depok, and protection line via Graha,the traffic will automatically move to another protection lines that are Jakarta - BSD - Graha - Kota Wisata - Depok - Bogor, as seen in Figure 16.

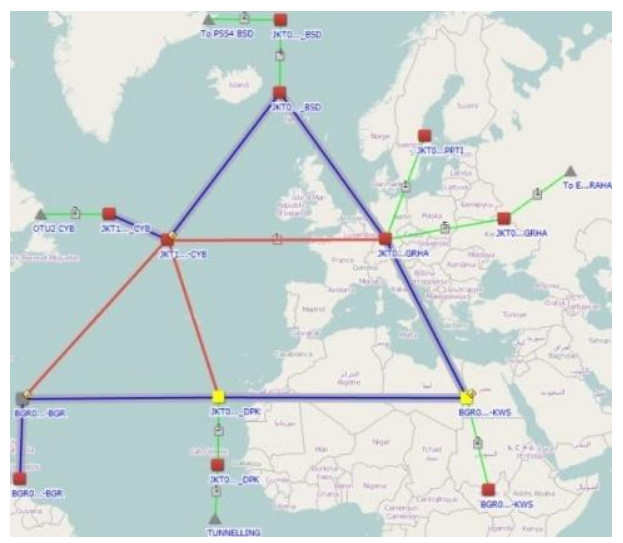

Fig. 16. Jakarta - Bogor Traffic via BSD.

From the measurement data of switching time and QoS at the line of Jakarta - Bogor protection link via Depok, Graha, and BSD, there are differences between the measurement and the calculation result which can be seen in table 9 below:

Table 9. Measurement and Calculation Results QoS Protection Link Jakarta - Bogor.

\begin{tabular}{c|cccccc}
\hline QoS & \multicolumn{2}{|c}{ via Depok } & \multicolumn{2}{c}{ via Graha } & \multicolumn{2}{c}{ via BSD } \\
Para- & Mea & Calc & Mea & Calc & Mea & Calc \\
meter & sure & ulati & sure & ulati & sure & ulati \\
\cline { 2 - 6 } & & & & & &
\end{tabular}




\begin{tabular}{|c|c|c|c|c|c|c|}
\hline & ment & on & ment & on & ment & on \\
\hline Swi- & 15,1 & 15.1 & 26,6 & 26.6 & 49,6 & 49.6 \\
\hline tching & 32.4 & 324 & 358 & 358 & 828 & 828 \\
\hline Time & $0 \mu \mathrm{s}$ & $\mathrm{ms}$ & $\mu \mathrm{s}$ & $\mathrm{ms}$ & $\mu \mathrm{s}$ & $\mathrm{ms}$ \\
\hline Throu & 10 & 9.97 & 10 & 9.97 & 10 & 9.97 \\
\hline ghput & Gbps & $\begin{array}{c}9 \\
\text { Gbps }\end{array}$ & Gbps & $\begin{array}{c}9 \\
\text { Gbps }\end{array}$ & Gbps & $\begin{array}{c}9 \\
\text { Gbps }\end{array}$ \\
\hline $\begin{array}{c}\text { Fra-me } \\
\text { Loss }\end{array}$ & $0 \%$ & $0 \%$ & $0 \%$ & $0 \%$ & $0 \%$ & $0 \%$ \\
\hline $\begin{array}{l}\text { La- } \\
\text { tency }\end{array}$ & $5 \mathrm{~ms}$ & $\begin{array}{c}5.20 \\
48 \\
\mathrm{~ms}\end{array}$ & $9 \mathrm{~ms}$ & $\begin{array}{c}8.58 \\
72 \\
\mathrm{~ms}\end{array}$ & $\begin{array}{l}12 \\
\mathrm{~ms}\end{array}$ & $\begin{array}{c}13.7 \\
284 \\
\mathrm{~ms}\end{array}$ \\
\hline Jitter & $0 \mu \mathrm{s}$ & $\begin{array}{l}4.63 \\
63 \mathrm{fs}\end{array}$ & $0 \mu \mathrm{s}$ & $\begin{array}{l}7.64 \\
93 \mathrm{fs}\end{array}$ & $0 \mu \mathrm{s}$ & $\begin{array}{c}0.01 \\
23 \\
\mathrm{ps}\end{array}$ \\
\hline
\end{tabular}

\section{Conclusion}

Based on the theory, calculation, simulation, and analysis in this thesis, there are conclusions as follows:

1. From the test and analysis results of QoS performed on ASON protection system in Jakarta - Bogor through the protection line via Depok, Graha, and BSD, it revealed the same result as QoS throughput $=10 \mathrm{Gbps}$; frame loss $=0 \%$; and jitter $=0 \mu \mathrm{s}$. But there is a difference in latency due to the addition of distance and node traversed. When it throughthe main line, the latency $=3 \mathrm{~ms}$; via Depok, Latency $=5 \mathrm{~ms}$; via Graha, Latency = $9 \mathrm{~ms}$; and via BSD, latency $=12 \mathrm{~ms}$. However, it did not affect the performance quality of throughput, frame loss, and jitter. Thus, ASON protection system wascapable to fill thetraffic needs on the main line.

2. From the test results and switching time analysis performed on ASON protection system in Jakarta - Bogor through the protection line via Depok, the switching time $=15.1324$ ms; via Graha,the switching time $=26.6358 \mathrm{~ms}$; and via BSD, the switching time = $49.6828 \mathrm{~ms}$. It can be concluded that the time required for the traffic to automatically switch when an interruption happened on the main line was $<50 \mathrm{~ms}$, thus the Service Level Agreement (SLA) standardization was maintained.

3. From the test and analysis results of ASON protection system, it can be concluded that ASON protection system was feasible to be applied because itscapability to handle multiple fault cases which was able to move automatically into the available protection line, thus able tokeep the traffic running normally.

\section{References}

[1]E. L. S. Sinaga, “Analisa Sistem Proteksi Jaringan DWDM Jakarta - Pekanbaru Menggunakan Serat Optik," Universitas Indonesia, 2011.

[2]S. Tomic, B. Statovci-Halimi, A. Halimi, W. Muellner, and J. Fruehwirth, "ASON and GMPLS:Overview and Comparison,” Photonic Netw. Commun., vol. 7, no. 2, pp. 111-130, 2004. 
[3]L. Raptis et al., "Design and experiments of an automatic switched optical network (ASON)," in Optical Communication, 2001. ECOC '01. 27th European Conference on, 2001, vol. 3, pp. 256-257 vol.3.

[4]G. Campiglia, "IP / MPLS over ASON / GMPLS networks Extension Of The GMPLS Control," Universitat politecnica de catalunya, 2012.

[5]A. Jajszczyk, "Control plane for optical networks: The ASON approach," China Commun., no. 1, pp. 113-122, 2004.

[6]ITU-T, "Recommendation G.8080/Y.1304: Architecture for the automatic switched optical networks (ASON)," Int. Telecommun. Union, 2012.

[7]ITU-T, "Recommendation G.8081/Y.1353, Terms and definitions for automatically switched optical networks," Int. Telecommun. Union, 2012.

[8]R.A. Krishna, "Study Paper On Automatically Switched Optical Network (ASON)," New Delhi, 2014.

[9]A. Jajszczyk and P. Rozycki, "Recovery of the control plane after failures in ASON/GMPLS networks," IEEE Netw., vol. 20, no. 1, pp. 4-10, 2006.

[10]S. Sánchez-López, J. Solé-Pareta, J. Comellas, J. Soldates, G. Kylafas, and M. Jaeger, "PNNI-Based Control Plane for Automatically Switched Optical Networks," J. Light. Technol., vol. 21, no. 11, pp. 2673-2682, 2003.

[11]T. Kushartadi, “ASON (Automatic Switch Optical Network),” 2010.

[12]F. Rudiana, "Analisa Sistem Proteksi Subnetwork Connection Protection Pada Perangkat ECI," Universitas Mercu Buana, 2016. 